\title{
THE MASK OF VIOLENCE.
}

\author{
CATHERINE MCINTOSH CARMICHAEL \\ Universidad de Glasgow. Reino Unido.
}

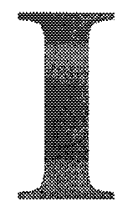

$\mathrm{n}$ this paper I discuss the view that violent behaviour is an uncontrolled response to some form of stimulation. The old view that violence is a basic human instinct that must be expressed in one form or another is now being challenged. behaviour more likely to be a physical response to the perception that behaviour more likely to be a physical response to the perception that the 'self', ie. one's sense of identity, is threatened. Being violated either emotionally or physically appears to result in a violent response. Violent behaviour can be seen as a mask which protects the 'self' from pain and memories of traumatic experiences. This new understanding requires us to look at and question current methods of dealing in our communities with the destructive effects of violent behaviour. In doing this I consider alternative approaches which may be more successful in reducing levels of destructive violence. I then want to look at how we respond to acts of violence, first as social workers and secondly as a society through the justice system when our attempts at intervention have broken down. Finally I want to offer some examples of how social work in co-operation with other agencies can help to create a new paradigm of work with violent offenders. These are presented both as a long term policy and also as direct methods of intervention. Opportunities for intervention are demonstrated in three case studies. The first is preventative in that it deals with a family in trouble where the children are already demonstrating their potential for violent and destructive behaviour; the second describes a new method of dealing with young offenders, described as mediation, within a framework of restorative rather than retributive justice. The third case study is of a small prison unit for very violent offenders, including murderers, which was turned into a therapeutic community and resulted in highly significant life changes for the inmates.

Social work has been mainly concerned with violence in personal relationships; the abuse of children, violence against women increasingly in Scotland we are becoming aware of violence by women against men. We have to recognize also violence against the self in 
acts of suicide. Increasingly however we are being consulted or involved in wider issues where violence is linked with social structures within which violence flourishes. I think of football violence, in my country we have sectarian violence between Protestants and Catholics, violence in school playgrounds, violence against other ethnic groups, violence against refugees. I do not think we can avoid responsibility for offering our skills in these areas as well as in one to one personal issues but equally I think we have to be cautiously realistic about what we do have to offer.

When I first joined the social work profession I was in a very privileged position. I was a psychiatric social worker in a small, high status, child guidance clinic. While I enjoyed the elite nature and intellectual stimulation of the setting the most important thing I learned there was the importance of working in a team of people drawn from different disciplines and of the necessity of involving not only the child but also parents in therapy. I have never forgotten that lesson. We all, as members of a profession, tend to look at issues through a single focus. We need to be questioned and challenged by colleagues who come from a different position, with different assumptions and a different perspective and also by our clients. I hope to show in this paper the importance of allying our skills to individuals and groups who, while some of them may not have our professional qualifications, may have important lessons to teach us.

Violence is an aspect of aggression, but no one would suggest that aggression is not an important, even desirable, human capacity. It is that capacity that we see in a red faced infant screaming a demand to be fed, it drives athletes to succeed, students to do well in exams, strangers to risk their lives to help someone in distress and the oppressed to demand justice; we attack problems, we struggle with difficulties. Aggression can underlie some of the greatest of human achievements and clearly we have to recognize that even the most unattractive aspects of aggression share identical roots with valuable and essential aspects of human endeavour. Yet there are many aspects of aggression we must reject. No other animal than the human takes positive pleasure in cruelty to its own kind. Murder, torture and war are human forms of behaviour only. Anthony Storr in his seminal study of human aggression writes, "The sombre fact is that we are the cruellest and most ruthless creature that ever walked the earth". I will speak later of how, as a social worker, I have seen some of those savage and violent impulses transformed into great creativity.

We are slowly realizing that we have no real understanding of aggression although our need to understand it has never been greater. There is not now any certainty that it is an instinct and the thought that 
we all carry innate drives which need to be discharged is being challenged in both biology and psychology. There are societies where aggression plays a very minor part in personal and community affairs. One of the few things we now think we know is that in the human creature there appears to exist a physiological mechanism which when stimulated gives rise to two things:

1. subjective feelings of anger,

2. physical changes which prepare the body for action.

The way we as individuals handle these changes differs widely from person to person and depends not only on the power of the stimulus but on age, background and training. It is when aggression breaks through or ignores the barriers that the surrounding society sees as necessary to maintain community stability that we begin to describe behaviour as violent. These barriers vary from society to society, within and between communities and also from one period of time to another. Some countries maintain the death penalty, the ultimate act of state violence and many see killing one's fellow human beings as acceptable in war time. In some countries like Egypt and Jordan torture is a legal and accepted part of state interrogation. The boundaries that contain or define violence can be quite elastic. We should recognize also that governments can use the human capacity for violence for their own purposes and some will choose to recruit into certain agencies of the state like police, prisons and the armed services those whom they can rely on to respond with high levels of aggression, and if necessary violence, to threats against the State.

I should start by explaining my title. I am arguing that when we encounter violence our first step should be to examine where its roots lie. Violence I believe is a mask which has the effect of protecting both the self and the 'other' from an awareness of the pain which triggers it. It is that pain which becomes the stimulus to which I referred earlier and that pain is the product of our experiences in interaction with other human beings in the course of our early development and later life. Those experiences define how we perceive ourselves and the 'other': both feeling and perception are involved in human destructive behaviour described as violence. Much of the basis for this thinking lies in the work, which will be familiar to you, of Bowlby and his attachment theory which emphasized the need for a secure base within which a child's confident personality can develop. This does not appear to happen within a family where violence against children is the norm. In his writings on violence within the family where children are being abused Bowlby emphasizes that this tends to happen where the parents themselves experienced violence in their own childhood. In other words if we hit children they will in turn hit others whenever they are in a situation that 
triggers the feelings they initially experienced. We see this in playground fighting or bullying where humiliating someone else may restore a young person's sense of self esteem when it has been damaged arising from shame at being ridiculed or hit. Attacks on a person's sense of self appear to overwhelm those acquired skills which enable a person to function with a sense of responsibility to themselves and others.

Children interviewed for a Scottish study by a group called, Children Are Unbeatable described their feelings after being hit by a parent or an adult in the following way.

You feel like hitting back, running away or hiding in a corner... Hurt, sore scared. Upset, unloved, terrified, worried, Ionely, sad, alone, abandoned, afraid, cross, frightened, sick, stunned, threatened, annoyed... hateful, emotionally hurt, ashamed..., resentful..., humiliated..., grumpy..., uncared for...It is bad, it makes you angry and you hate the parent for five hours.

What fascinated me about children using these words was that they are echoed in the work of the American psychiatrist James Gilligan much of whose work is concerned with murder and murderers. Gilligan argues that the traditional moral and legal approach to violence actually stimulates violence rather than preventing it. The current view still assumes that the deliberate infliction of pain by some form of punishment, whether in the family or in the courts, prevents violence. It may indeed cause a temporary shock and halt, but that effect will not last. There is no evidence that it works long term. On the other hand there is a growing body of evidence to support the opposite view -that punishment is the most powerful stimulus to violent behaviour that we have yet discovered. Punishment does not prevent violence -it causes it. Gilligan argues that violence should be thought of, not as a moral and legal problem but as a problem in public health and preventative medicine. This approach seems particularly appropriate in domestic violence but I would argue that if we think of public heath as including community medicine it is equally relevant for the wider forms of violence which I have called structural. This is an important insight, provided we remember and guard against the abuse of it that arose in Soviet mental hospitals set up to deal with dissidents.

As I said earlier we are only beginning to understand what is involved in these questions. One of the most recent research studies indicates that feeling shame, being ridiculed or treated with disrespect produces shame which leads to rage. The sociologist Scheff describes the "shame rage spiral". "As humiliation increases, rage and hostility increase proportionately to defend against the loss of self esteem'. Gilligan said, "I have yet to see a serious act of violence that was not provoked by the experience of being shamed and humiliated, disrespected and 
ridiculed ...", the violence he went on to say, was an attempt to prevent or undo this 'loss of face' -no matter how severe the punishment that might follow.

Interestingly, this thought had also been expressed by both Aristotle and Thomas Aquinas. Gilligan, aware of the research happened to reread the story of Cain and Abel. He says that for the first time he really 'heard' what the story was saying. It became clear to him why Cain killed Abel. I quote what the Bible says, "The Lord had respect to Cain and his offering: But unto Cain He had not respect". In other words Cain was shamed and his reaction was murderous anger.

The social causes of shame leading to violence include low status, poverty and unemployment which lead to feelings of inequality and inferiority. Racial discrimination does the same. In many societies and subcultures the ability to be violent is seen as a proof of masculinity and is supposed to command respect. The Greek word for masculinity, andreia, also means courage. After September 11 th. it was said that Bush could not be seen to be anything else but violent in his response to the attacks on New York. The American people it was said, would not stand for it. He would have been seen as a coward.

The philosopher Hegel identified the desire for recognition of the self as the central motive force behind all of human history and history is of course largely the history of violence. Karl Marx agreed with Hegel to the extent of recognizing that shame is the emotion of revolution. Let me explain what I mean by that. Shame as I have said earlier is an emotion we feel when we are not recognized or respected. Not to be recognized or respected is an attack on the core of the self. It is as if our existence is denied; we are seen, not as a person but as an object, a thing. Psychologists and sociologists are now arguing that the purpose of violence is to force respect from other people. Famous criminals frequently surround themselves with subordinates from whom they demand respect. I think violent behaviour at football matches and in school playgrounds comes into the same category. It also helps us to understand reactions of violence from the general public when they feel they have been treated with disrespect by officials in public offices. We can see how a man who is offered no respect may find in his wife wife, partner or children a target for displaced rage. In revolutions the oppressed are demanding to be heard and to be taken seriously and that may also have been a motivating factor behind the attack on the Twin Towers in New York on September 11th.

If we believe this and if we turn to preventative measures, we have to recognize that two strategies are necessary -one for the long term and one for short term intervention. For the first we require to set in place in all our institutions, by which I mean the family, schools, hospitals 
and public offices, a set of principles that reflect our goals for a nonviolent society. There are two main principles involved.

1. By treating everyone with respect from childhood on, you teach them to treat others with respect also. The only effective teaching is by example. For this reason the Scottish Parliament is attempting to introduce legislation to make illegal the physical punishment of children under three. Many of us would like to ban it for all ages but we feel this is a first step and if parents can manage this they will be less inclined to use physical punishment at a later age.

2. Just as the most powerful provocation to violent behaviour is disrespect, so the most powerful means of preventing violence is universal respect.

That as I have said is the long term strategy. The other strategy relies on more direct intervention, often through the justice system. This is what Gilligan and others concerned with violent behaviour are challenging. The justice system is based on a retributive model in most countries, that is to say violent behaviour by a citizen is seen as a violation of the state defined by law breaking and guilt. This type of justice determines blame and administers pain in a contest between the offender and the state. The process is governed by systematic, impersonal rules. Such proceedures appear to reinforce rather than reduce violent behaviour. A new paradigm based on some of the research I have mentioned is described as restorative justice in which violence, along with all crime, is seen as violation of people and relationships. It creates an obligation to put things right -to restore. This justice involves the victim, the offender and the community in a search for solutions which promote repair, reconciliation and reassurance.

If we turn to forms of intervention which have these goals in mind it is helpful to look at some examples. You may remember that Bowlby vividly described the hard work involved in being a successful parent. We can still see the help given parents in pre-industrial societies by all members of the extended family and reckon this may have been the practice in Europe before industrialization destroyed those supports. Parents still need support and Barnardo's is a voluntary society concerned with the needs of children which recognizes the needs that parents in trouble have for support. They often have children and families referred to them who are struggling with very difficult behaviour, the children are often excluded from school and parents are feeling that their families are very much out of control. Barnardo's Matrix Project provides early special support to families whose children are 8-11years, are or are at risk of, developing anti-social and/or offending behaviour with the aim of reducing identified risk factors and enhancing protective 
factors. They work to an ecological model which aims to enhance children's development by intervening in all the systems that impact on the child. A number of the risk factors for persistent offending link directly to physical punishment and as I have said earlier we now know there is a link between physical punishment and later violent offending. But since families are often struggling with very difficult behaviour and school exclusion parents may resort to harsher and harsher punishment.

Working with parental needs is as important as working with the children and in this project Barnardo's offers individual weekly sessions for parents with a dedicated project worker and also a parent's support group. They describe the work with one family with four children between the ages of 6 and 14 all of whom had been on the Child Protection Register for physical abuse by the parents. The children were engaged in anti-social behaviour at home, in school and in the community. They were completely out of control and physical punishment was not working.

The Barnardo's worker worked with a local authority social worker in what became a very challenging and demanding schedule which involved looking both at children's rights and parent's responsibilities. The whole family met with the workers and looked at the rules and routines in the home. These were chaotic. The children weren't coming home in time said the parents -but there were no set times. Mother and Father agreed to have an evening meal ready at the same time every night and the children agreed to come home for it. Other patterns were agreed. A white board was set up in the kitchen with all the agreements clearly laid out including the day's menu and all the family were committed to the plan. The workers took turns in being with the family four evenings a week. If a child didn't turn up the worker would go out with the parent to find them. Gradually the routine began to fall into place. Alongside this, family outings were organized partly as rewards for hard work but also to give the family the experience of happy times together. Ultimately a situation where no one was in control was turned round by careful planning where the parents were active participants. They haven't just learned ways to control their children, but a whole new approach to family life which negates the need for violence.

It is interesting that when this project started Barnardo's offered a parenting skills group to families whose children were in trouble. No one responded. They then invited them to an 'open day' which got a good response and the parents raised all the issues the workers had wanted to discuss under the heading of parenting skills. These were questions about child development and the role parents play, communication with one's children, stress management and children's 
rights and responsibilities. The difference was that it was the parents who brought up the issues. These meetings need also to address the low esteem in which parents who have lost control hold themselves. This is vitally important since low self esteem in parents will be reflected in the children's view of themselves and we have seen how this in turn leads to violent reaction on both sides to anything seen as an insult. At this point you may want to look at the list of risk and protective factors which influence children's development within the family and community. The 'risks' are danger signals; 'protective factors' are thos things that help to protect children against these dangers. This list is currently being found helpful in one Scottish Local Authority. I will be happy to explain at question time the meaning of any words not familiar to you.

Risk and protective factors related to violence can be assessed at four levels: the individual, the family, the school and community, and the wider world.

\section{INDIVIDUAL}

RISK

Offending behaviour.

Anti-social behaviour.

Poor physical health.

Poor attachment to carers.

Use of drugs/alcohol.

\section{FAMILY}

RISK

Poor parental management techniques.

Harsh or neglectful parenting.

Poor supervision of children.

Offending by family members.

\section{SCHOOL/COMMUNITY}

\section{RISK}

Low attainment.

Poor school attendance.

Anti-social behaviour.

Truancy/exclusion

Disadvantaged community.

Lack of community involvement.

Disorganization.

\section{PROTECTIVE}

Good health and development.

Good problem solving skills.

Strong bonds in infancy.

\section{PROTECTIVE}

Good parenting skills.

Good relationship with parents.

Strong attachment to family.

No early prolonged separations.

\section{PROTECTIVE}

Good attainment.

Good links home/school.

Good 'ethos', no bullying.

Positive peer influences.

Strong social support network.

Opportunities for involvement.

Achievement. 


\section{WIDER WORLD}

RISK

Economic recession.

Unemployment.

Family change.

\section{PROTECTIVE}

Inclusive policies.

Community schools.

Early years provision.

Fragmented communities and availability of drugs.

Currently, the Scottish Executive, our term for the Scottish Government, is investing two million pounds in a project to help in the prevention of recidivism in young offenders who have behaved in violent ways both against property and against people. This is being administered by SACRO, the Scottish Association for the Care and Rehabilitation of Offenders. The system used is known as 'conferencing' and is an example of the use of restorative justice. I said earlier that the traditional legalistic approach to violent behaviour-retributive justice, is increasingly being seen as reinforcing violence rather than minimising it.

I will describe the new approach of restorative justice. Where the offender admits guilt he or she -more often he of course- is brought face to face with their victim -if victims agree to meet them. These victims are supported by family or a neighbour or anyone whom they want to help them express how this incident has affected them. The offender also has support from family and friends. The occasion is chaired by a mediator who understands the importance of both parties expressing themselves freely, but equally of retaining the self respect of both. Restoration normally starts with an apology for the offence. That appears to have a powerful healing function for the victim as does the opportunity to have their feelings listened to respectfully. The offender may also agree to do practical things like helping physically to repair any damage done, eg. in housebreaking or car theft. These techniques require quite new skills for the professional people involved and social workers have to learn these. It involves working with other people and recognizing that individuals without professional qualifications may have skills with which we can collaborate. People in the local community are also trained as mediators and community strengths developed to handle local incidents so that when the SACRO staff leave, the community should be better equipped to sort out their own problems.. Transcendental meditators say that if one in a hundred people could be taught to meditate regularly we would have a peaceful society. The same principle may apply to mediators. The basis of all this work depends on close co-operation with the police and the justice system

The last example I want to give is of a Scottish prison experiment with violent men, including murderers, who had proved unmanageable in normal prisons. The were brought together in a small unit with a 
hand picked staff of prison officers and back-up from a psychiatrist, psychologist, psychiatric social worker and art therapist. Staff ratios were high. The regime, agreed before the unit opened, was simple. Meeting of staff and prisoners were held regularly, more often if there were problems to discuss. All staff and prisoners had to attend and agree on any action to follow. Separate staff and prisoner meeting were not allowed. There was no separate staff office where staff could take refuge. All cells were open. Families were allowed open visits which allowed physical contact like hugging.

One prisoner with a dramatically violent history, described by the press as the most violent man in Scotland, repeatedly beaten by prison officers and previously confined in a cage without privacy was among the first intake. Arriving in a hostile and rather frightened state he was welcomed and initially addressed politely as Mr Boyle. Later prisoners and staff used first names. One day when he was struggling to open a parcel sent to him, the senior prison officer produced a pair of scissors and handed it to him. It was a mark of trust and respect from one human being to another and was a turning point in that prisoner's life. Introduced to working with clay by the art therapist he went on to become a remarkable sculptor and writer. While not every member of the special unit achieved such fame, all were profoundly influenced and none have re-offended. The invitation to Jimmy Boyle's coming out party read -"A celebration of freedom symbolising a beginning as well as an end-signifying renewal as well as change". You will not be surprised to learn that the prison authorities closed the unit down saying it was too expensive to run. The shift in power was too threatening. What we hope for in the future is the introduction into the prison system of the mediation process where victims can take part in a conferencing process within the prison to meet their offenders.

Summing up is not easy but I will try to lay out the basic message.

We should not accept the idea that violence is a basic instinct. It is a response to stimuli that we can question and change in the family, the community and in the wider society. We must hold to the idea that violent responses to violence leads to more violence and that the traditional justice approach to violence, based on a retributive model, appears to reinforce rather than reduce violent behaviour. The alternative is to develop in co-operation with other agencies, wherever possible, the principle of restorative justice. This is essential if we are to learn how to live together.

This paper is also a tribute to one of my dearest friends, David Brandon, who died this year. He had been the victim of brutal and violent beatings from his father, grew up rebellious and with a hair trigger temper which led him to leave home and live on the streets. 
Here, meeting other homeless youngsters he began to assess what was happening to him, returned home and went to university where he ultimately trained in social work. He specialized in working with homeless young people and found spiritual peace in the practice of Buddhism. His life represents for me the triumph of the human spirit in its creative response to pain and trauma. Using this experience he made the same possible for countless others.

\section{Postscript on Old and New Paradigms of Justice}

\begin{tabular}{|ll|}
\hline Old: Retributive Justice & New: Restorative Justice \\
Crime defined as violation of the State. & $\begin{array}{l}\text { Crime defined as violation of one person } \\
\text { by another. }\end{array}$ \\
Focus on establishing guilt and the past. & Focus on problem solving and the future. \\
Adversarial relationships. & Dialogue and negotiation. \\
Justice defined by process: Were right & Justice defined as right relationships: \\
rules followed. & judged by outcome. \\
Community sidelined. & Community involved. \\
Victim ignored, offender passive. & Victim and offender's roles recognized. \\
Offender accountability: taking & Offender accountability includes \\
punishment. & understanding and helping repair damage. \\
Offence defined in legal terms. & Offence understood in moral, social, \\
Response focussed on offender's & economic, political context. \\
behaviour. & Response focussed on harmful past \\
Little encouragement for repentance & consequences of behaviour. \\
and forgiveness. & More possibilities for repentance and \\
Dependence on professionals. & Dergiveness.
\end{tabular}

This has been slightly adapted from Howard Zehr, Retributive Justice; Restorative Justice. 